Acta Horticulturae et Regiotecturae - Special Issue

Nitra, Slovaca Universitas Agriculturae Nitriae, 2021, pp. 117-123

\title{
CLIMATE CHANGE IMPACT ON METEOROLOGICAL DROUGHT AND SOIL WATER STORAGE IN THE NITRA RIVER BASIN FOR THE PERIOD 2015-2019
}

\author{
Vladimír KIŠŠ*, Andrej TÁRNÍK, Ján ČIMO \\ Slovak University of Agriculture in Nitra, Slovakia
}

\begin{abstract}
Drought impacts are significant and widespread on a year-to-year basis, affecting many economic sectors and people at any time. Definitions of drought are clustered into four types: meteorological, hydrologic, agricultural, and socio-economic. In our paper we focus on the comparison of meteorological drought (defined as a period with no precipitation) and agricultural drought (determined as the value below the amount of water storage in the soil profile accessible to plants). The meteorological stations of the Department of Biometeorology and Hydrology of the Slovak University of Agriculture (SUA) in the Nitra River Basin (Slovakia) Bystričany, Solčany and Palárikovo - were used for the research. Soil moisture was recorded at horizons 0-0.15 m and 0.15-0.30 m. The occurrence of meteorological as well as agricultural drought in the Bystričany locality has changed quite significantly not only in the summer months but also in the autumn and often in the spring. Meteorological drought in the Solčany locality occurs regularly almost throughout the whole year. Agricultural drought is becoming more regular in the last monitored years. In Palárikovo (the southernmost locality) the occurrence of meteorological drought is regular and even occurs in the spring and autumn months. Agricultural drought also occurs regularly. To increase agricultural production, it is necessary to focus not only on meteorological drought, but also on agricultural drought and soil characteristics in individual localities. We analysed the drought to the depth of $0.30 \mathrm{~m}$, but in the deeper layers there may be enough moisture for the crops' root systems.
\end{abstract}

Keywords: meteorological drought, agricultural drought, drought period, basin, precipitation

Drought is a normal part of the world climate, and it can occur in any climate regime around the world, even deserts and rainforests (WMO \& GWP, 2016; Lecina-Diaz et al., 2020). Drought is one of the more costly natural hazards on a yearto-year basis; its impacts are significant and widespread, affecting many economic sectors and people at any time (Zhong, Cheng, Wang, 2020; Engstrőm, Jafarzadegan, Moradkhan, 2020). Drought is one of the deadliest natural hazards, and the universal definition of the term has proven to be elusive yet (Lloyd-Hughes, 2013). According to Palmer (1965) a drought period may be defined as an interval of time, generally of the order of months or years in duration, during which the actual moisture supply at a given place rather consistently falls short of the climatically expected or climatically appropriate moisture supply. The discussion of the disciplinary perspectives of drought which follows is the result of a review of more than 150 published definitions (Coles, Eslamian, 2018). For purposes of discussion, these definitions of drought are clustered into four types: meteorological, hydrologic, agricultural, and socio-economic (Wilhite, Glantz, 1985; Dracup, Lee, Paulson Jr, 1980).

Meteorological drought refers to the abrupt absence of or deficiency in precipitation in comparison with the "normal" condition. The "normal" precipitation is represented by a long-term mean value (generally 30 years or more) of precipitation of the concerned station or region (Bhuiyan, 2017; Quiring, 2009). Hydrological drought refers to a lack of water in the hydrological system, manifesting itself in abnormally low streamflow in rivers and abnormally low levels in lakes, reservoirs, and groundwater. It is a part of the bigger drought phenomenon that denotes current natural hazard (Van Loon, 2015; Stahl et al., 2020). Agricultural drought is considered to have set in when the soil moisture availability to plants has dropped to such a level that it adversely affects the crop yield and hence agricultural profitability (Mannocchi, Todisco, Vergni, 2004; Toková, 2019). In brief, the definition of agricultural drought is concerned with the soil moisture deficiency in relation to meteorological drought and climatic factors and their impacts on agricultural production and economic profitability (Łabędzki, Bąk, 2014; Seshasai, Murhy, Chandrasekar, Mohammed, Prabir, 2016). The first three types of droughts are viewed as physical phenomena, and socioeconomic drought is associated with local water supply, which tracks water demand through socioeconomic systems. As population, industries and urbanization grow, the water demand increases, and socioeconomic drought becomes a major concern (Mehran, Mazdiyasni, AghaKouchak, 2015; Tu, Wu, Singh, Chen, Lin, Xie, 2018). Socioeconomic drought thereby refers to the condition that water supply cannot satisfy demand, leading to societal and

Contact address: Vladimír Kiššs, Slovak University of Agriculture in Nitra, Faculty of Horticulture and Landscape Engineering, Department of Biometeorology and Hydrology, Hospodárska 7, 94901 Nitra, Slovakia, $\mathbf{m}$ +421 3764152 47, e-mail: vladimir.kiss@uniag.sk; ORCID: https://orcid.org/0000-0002-8527-2958 
economic disruptions, and environmental impacts (Eklund, Seaquist, 2015; Guo et al., 2019).

Several common features of drought propagation have been revealed, such as droughts getting longer in duration in moving from meteorological to soil moisture to hydrological drought (Wang, Ertsen, Svoboda, Hafeez, 2016). In our paper we will focus on the comparison of meteorological and agricultural drought in the Nitra river basin, Slovakia.

\section{Material and methods}

The meteorological stations of the Department of Biometeorology and Hydrology of the SUA in the Nitra River Basin (Slovakia) were used for the research (Figure 1). This basin extends between two basins - the Váh basin from the north and west and the Hron basin from the east. The total area of the Nitra river basin is 4,501 km² (Mazúr, Lukniš, 1980; Borgula, 2020). At selected stations - Bystričany, Solčany and Palárikovo (Figure 1), soil moisture was recorded at horizons $0-0.15 \mathrm{~m}$ and $0.15-0.30 \mathrm{~m}$. Total precipitation was provided from the Slovak Hydrometeorological Institute.

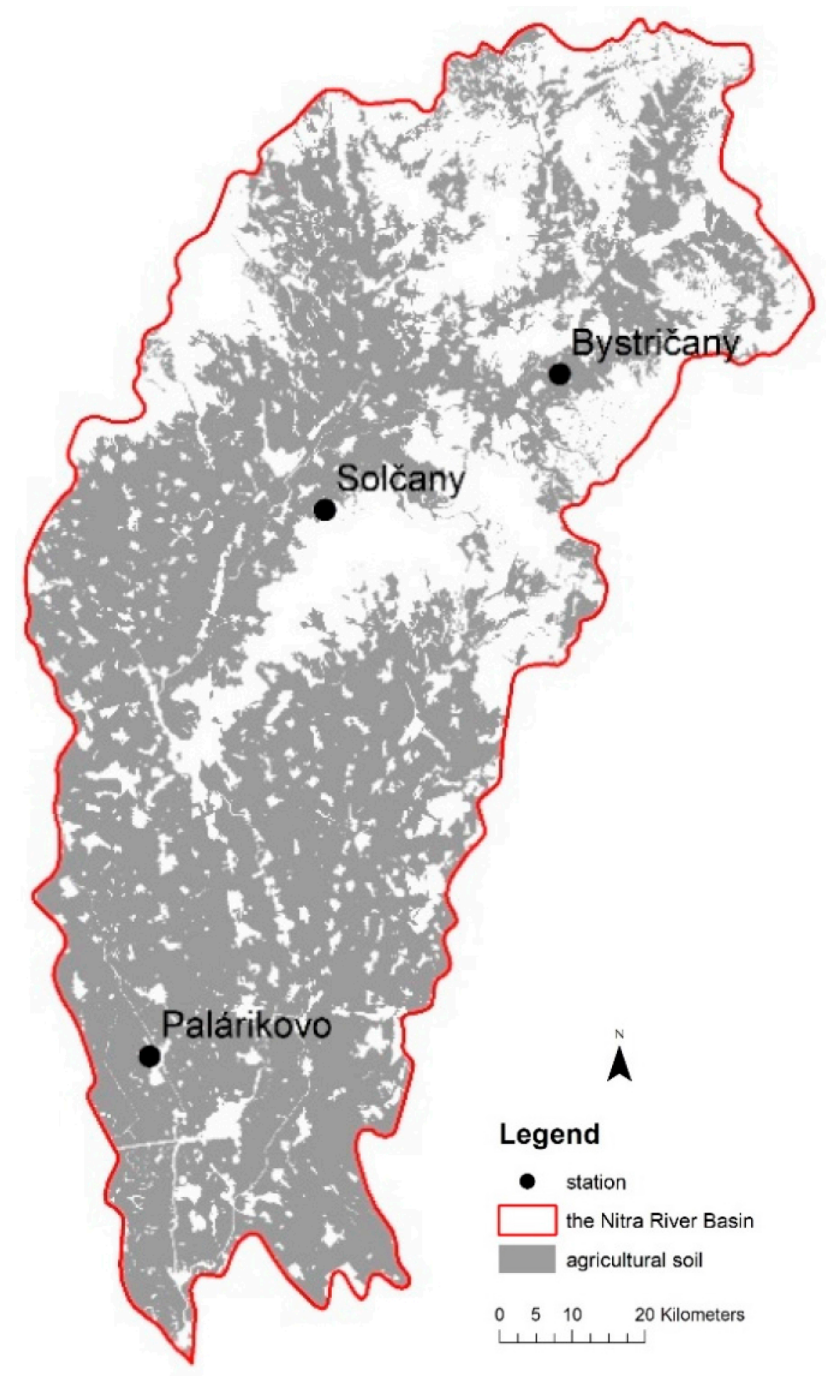

Figure 1 The Nitra river basin
Meteorological drought was defined as a period with no precipitation for purpose of this study. In this paper, the evaluation criterion is used as in Petrovič (1960). Dry periods are divided into three groups according to the number of consecutive days without precipitation:

a) 5 days and more (5-9 days);

b) 10 days or more (10-19 days);

c) 20 days or more, the day of $0.1 \mathrm{~mm}$ rainfall not interrupting the dry season.

Agricultural drought is not measured as a direct function of precipitation and hydrological availability of water, because soil types vary in their water uptake and holding capacity, and crops have different moisture needs (Wandel, Diaz, Warren, Hadarits, Hurlbert, Pittman, 2016; Báreková, Bárek, Kováčová, Novotná, Kišš, 2020).

To assess the available water storage in the soil for vegetation cover, the characteristic points of the moisture retention curve (characteristic states of retention-water content in the soil) are selected on the basis of a convention (Kutílek, Nielsen, 1994):

a) wilting point corresponding to $\mathrm{pF}=4.18$ (it is such soil moisture when the plant cover is permanently insufficiently supplied with water from the soil and withers);

b) a point of reduced availability corresponding to the value of $\mathrm{pF}=3.3$ (characterized by soil moisture at which the physiological processes of the plant cover are limited by the deficiency);

c) field water capacity corresponding to the value $\mathrm{pF}=2.0$ to 2.7 (characterized by soil moisture, which is maintained in the soil profile for a relatively long time, while the aeration of the soil is still sufficient for the development of plant cover (Šútor, Gomboš, Mati, 2005).

Agricultural drought was determined as the value below the amount of water storage in the soil profile accessible to plants calculated from the formula (Antal et al., 2014):

$$
W_{R}=\sum_{i=1}^{n}\left(\theta-\theta_{V}\right)_{i} \times h_{i} \quad(\mathrm{~mm})
$$

where:

$\theta_{i} \quad$ - current soil moisture of the $i$-th layer $\left(\mathrm{m}^{3} \cdot \mathrm{m}^{-3}\right)$

$\theta_{v, i} \quad$ - wilting point of the $i$-th layer $\left(\mathrm{m}^{3} \cdot \mathrm{m}^{-3}\right)$

$h_{i} \quad$ - the thickness of the $i$-th layer of the soil profile $(\mathrm{mm})$

The water storage $\left(W_{R}\right)$ was calculated as the sum of the values for the horizon $0-0.15 \mathrm{~m}$ and $0.15-0.30 \mathrm{~m}$. The wilting point values were taken from Igaz, Štekauerová, Horák, Kalúz, Čimo (2011), where they determined the soil properties of 111 samples taken from the Nitra river basin.

We compared meteorological and agricultural drought in each year from March to November, which is the month before the beginning and the month after the end of the growing season. Due to the climate change, the length of the growing season of agricultural crops is also changing (Čimo et al., 2020; Sar, Avci, Avci, 2019; Plich, 2017). Climate anomalies that occur during these periods will have a large impact on vegetation growth (Chen, 2018). 


\section{Results and discussion}

Several factors can be considered when assessing drought in a landscape. The basic indicator of drought in the landscape is the meteorological drought, which evaluates precipitation less periods. However, for the purposes of agricultural practice, it is only a secondary indicator. The soil water content and thus the assessment of soil drought is essential for growing crops.

The disadvantage of assessing drought based on precipitation is that it interrupts the meteorological drought. However, soil drought may continue. The analysis of the data shows that soil drought is often not interrupted by rainfall with a daily total above $10 \mathrm{~mm}$ and even above 20 $\mathrm{mm}$ or is interrupted only for a very short time.

It is a long-standing fact that the distribution of precipitation is changing. Several sources (De Luis, Gonzalez-Hidalgo, Longares, Stepanek, 2008; De Luis, Cufar, Saz, Longares, Ceglar, Bogataj, 2014; Salman, Shahid, Ismail, Ahmed, Chung, Wang, 2019) report a decrease in precipitation in the spring. This potentially causes a problem for the growth of the new crop. Our measurements and analyses also confirm the recurrence of meteorological drought. Nevertheless, in the spring there is no decrease in soil moisture, the critical limit of the point of reduced availability.

Recently, however, this trend has been changing. The trend of movement of the occurrence of agricultural

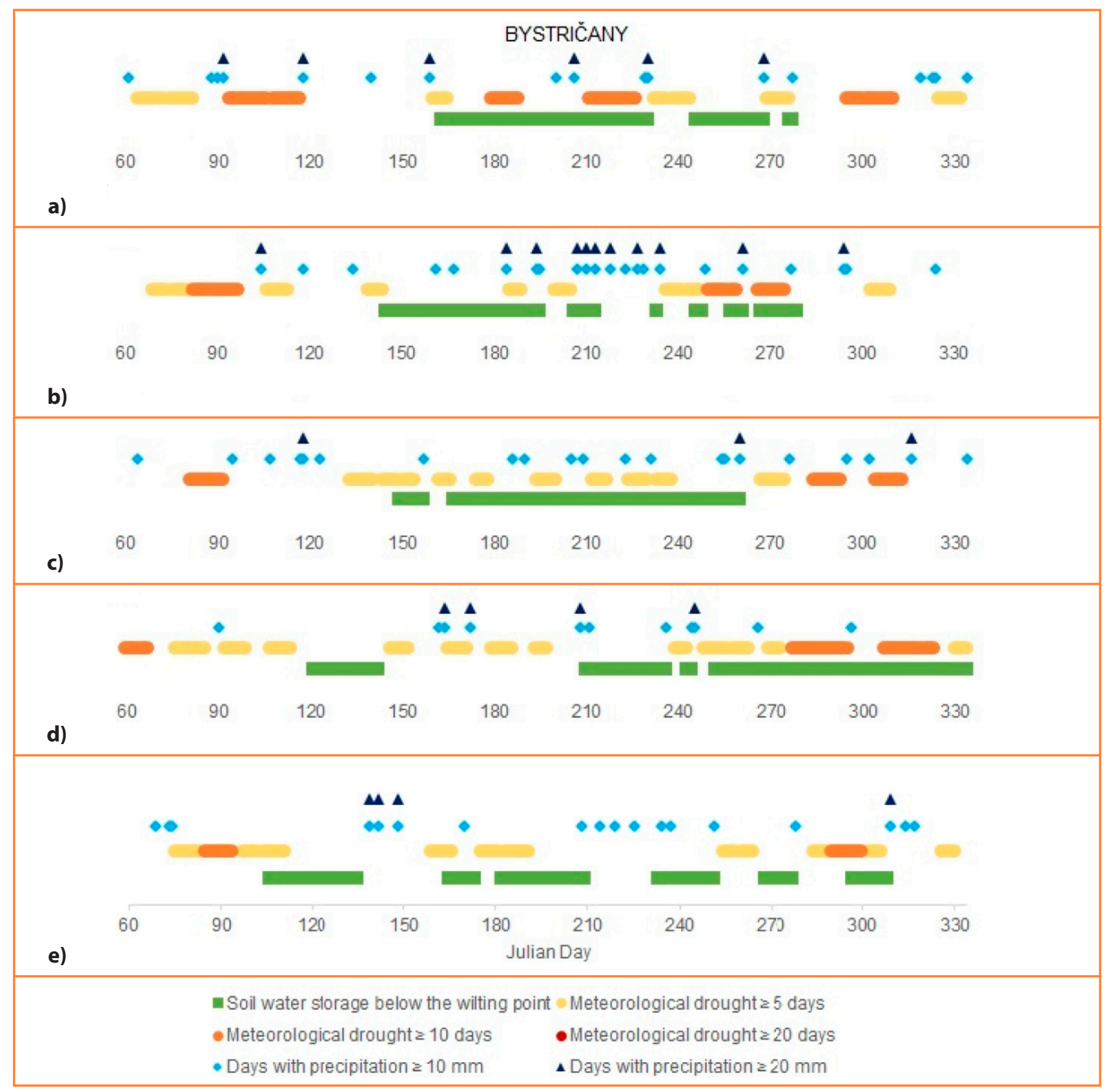

Figure 2 Comparison of meteorological and agricultural drought in the locality of Bystričany for years: (a) 2015; (b) 2016; (c) 2017; (d) 2018 a (e) 2019 
drought to the spring period can be observed in the locality Bystričany and in the long term also in the locality Palárikovo. While the Palárikovo locality is the southernmost monitored locality in the middle of the lowlands, the Bystričany locality is in the northern part of the territory in a relatively undulating landscape.

Another negative trend is the prolongation of the duration and continuity of the occurrence of agricultural drought. This trend is clearly visible in the localities of Bystričany, Solčany and Palárikovo.

The occurrence of meteorological as well as agricultural drought in the Bystričany locality has changed quite significantly (Figure 2). At the beginning of the observed period, meteorological drought occurred relatively frequently, but its occurrence was not continuous (Figure 2a). In recent years, drought has occurred not only in the summer months but also in the autumn and often in the spring (Figure $2 \mathrm{~b}-2 \mathrm{e}$ ). At the same time, the individual dry seasons merge into longer periods.

Meteorological drought in the Solčany locality (Figure 3) occurs regularly almost throughout the whole year. However, agricultural drought is becoming more regular only in the recent monitored years (Figure $3 c-3 e$ ). At the beginning of the research, the agricultural drought almost did not occur (Figure 3a-3b). Here we observe the adverse consequences of the climate change when the meteorological prolongation occurs, at the same time as the occurrence of agricultural drought.

Palárikovo is the southernmost monitored locality. In this location, the changes are most pronounced. The occurrence

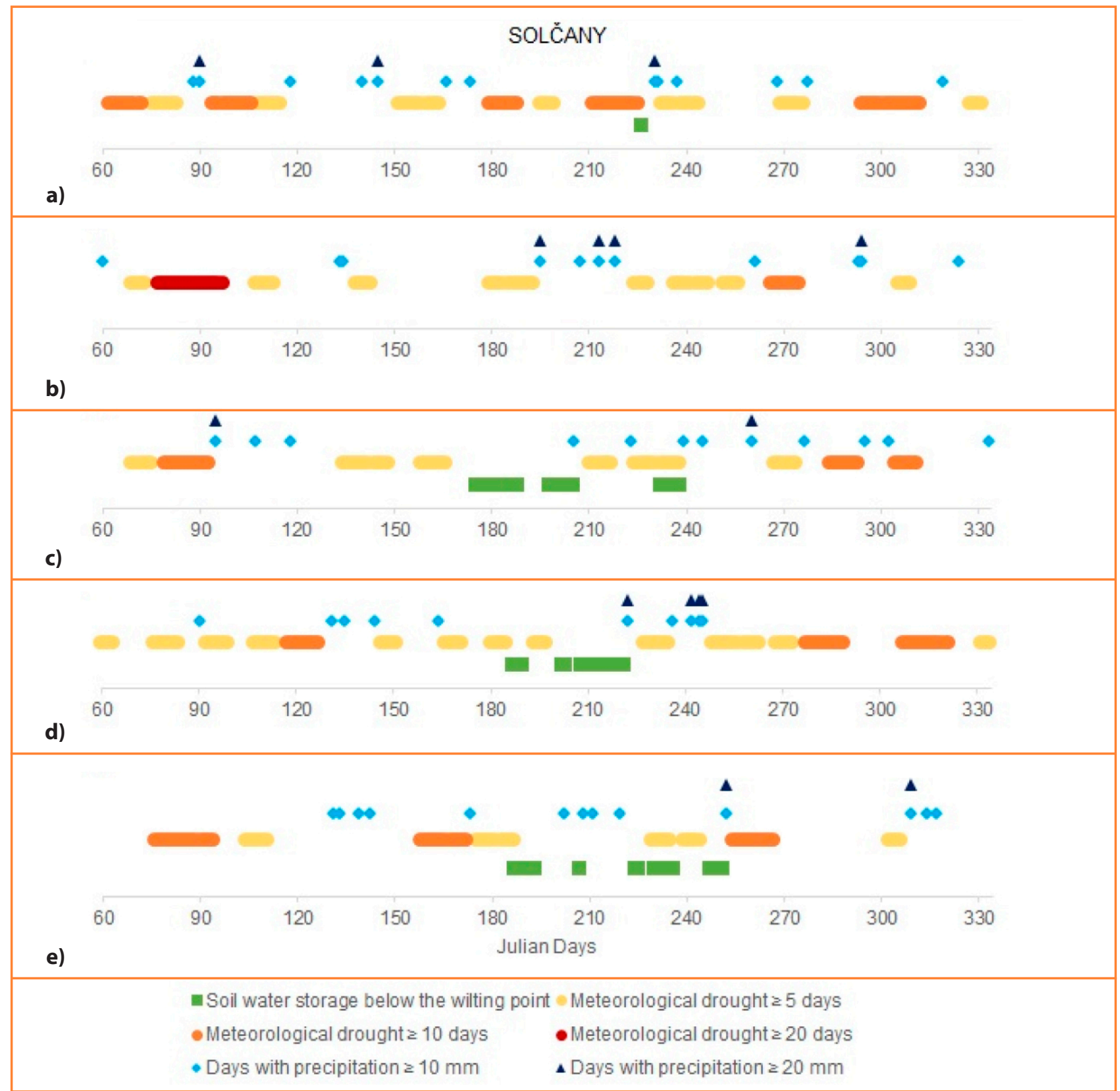

Figure 3 Comparison of meteorological and agricultural drought in the locality of Solčany for years: (a) 2015; (b) 2016; (c) 2017; (d) 2018 a (e) 2019 


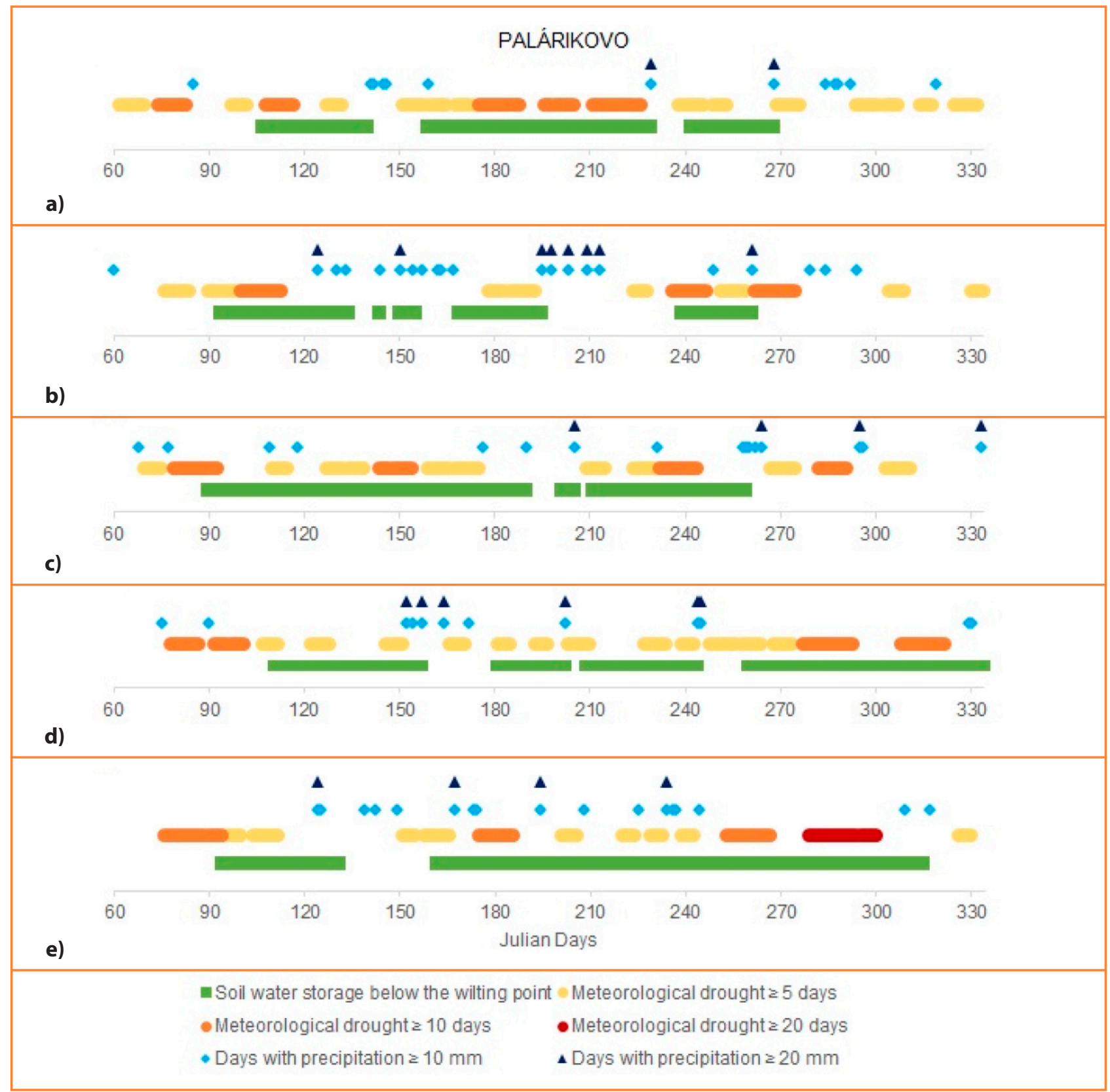

Figure 4 Comparison of meteorological and agricultural drought in the locality of Palárikovo for years: (a) 2015; (b) 2016; (c) 2017; (d) 2018 a (e) 2019

of meteorological drought is regular and even occurs in the spring and autumn months (Figure 4a-4e). The periods are both continuous and longer. Agricultural drought also occurs regularly. We also monitor its prolongation and its movement into the spring and autumn months.

Table 1 shows the number of days with the occurrence of agricultural drought in the months from March to November in the years 2015-2019 in each of the localities.

Several factors need to be considered when comparing meteorological and agricultural droughts. In this work, we considered the period without precipitation and with precipitation up to $0.1 \mathrm{~mm}$ as a meteorological drought. Brezianská and Vitková (2015) consider days without precipitation and days with precipitation up to $3 \mathrm{~mm}$ as meteorological drought. Using this methodology, the length of meteorological drought in our selected localities would be significantly extended. In recent years, not only in Slovakia, but unevenly distributed precipitation-free periods and periods of intense precipitation have been recorded worldwide, mainly at the regional level (Zhai, Zhang, Wan, Pan, 2005; Pal and Al-Tabbaa, 2009). Several authors (Vitková, Šútur, Šurda, Stradiot, 2015; Šútor, Šurda, Štekauerová, 2011) consider soil drought below the wilting point, which we also used in our work and reflected the water supply available to plants.

However, in order to increase agricultural production, it is necessary to focus not only on meteorological drought, but also on agricultural drought and soil characteristics in individual localities. In this work, we analysed the drought to 
Table 1 Number of days with agricultural drought

\begin{tabular}{|c|c|c|c|c|c|c|c|c|c|}
\hline & III. & IV. & v. & VI. & VII. & VIII. & IX. & $\mathrm{X}$. & XI. \\
\hline \multicolumn{10}{|c|}{ Bystričany } \\
\hline 2015 & 0 & 0 & 0 & 14 & 31 & 18 & 23 & 2 & 0 \\
\hline 2016 & 0 & 0 & 8 & 30 & 21 & 1 & 16 & 5 & 0 \\
\hline 2017 & 0 & 0 & 3 & 21 & 31 & 31 & 17 & 0 & 0 \\
\hline 2018 & 0 & 0 & 22 & 0 & 3 & 25 & 23 & 31 & 30 \\
\hline 2019 & 0 & 15 & 15 & 9 & 28 & 11 & 14 & 12 & 4 \\
\hline \multicolumn{10}{|c|}{ Solčany } \\
\hline 2015 & 0 & 0 & 0 & 0 & 0 & 1 & 0 & 0 & 0 \\
\hline 2016 & 0 & 0 & 0 & 0 & 0 & 0 & 0 & 0 & 0 \\
\hline 2017 & 0 & 0 & 0 & 0 & 15 & 7 & 0 & 0 & 0 \\
\hline 2018 & 0 & 0 & 0 & 0 & 11 & 9 & 0 & 0 & 0 \\
\hline 2019 & 0 & 0 & 0 & 0 & 8 & 9 & 5 & 0 & 0 \\
\hline \multicolumn{10}{|c|}{ Palárikovo } \\
\hline 2015 & 0 & 14 & 20 & 22 & 31 & 19 & 25 & 0 & 0 \\
\hline 2016 & 0 & 28 & 17 & 17 & 13 & 6 & 17 & 0 & 0 \\
\hline 2017 & 1 & 30 & 31 & 30 & 16 & 31 & 16 & 0 & 0 \\
\hline 2018 & 0 & 11 & 31 & 8 & 25 & 31 & 16 & 31 & 30 \\
\hline 2019 & 0 & 27 & 11 & 20 & 31 & 31 & 27 & 31 & 11 \\
\hline
\end{tabular}

the depth of $0.30 \mathrm{~m}$, but in the deeper layers there may be enough moisture for the root system of the crops.

\section{Conclusions}

More frequent periods of drought are visible more and more often in Slovakia. In this work we compared the dependence between meteorological drought and agricultural drought, which are interesting from the agricultural point of view. In the selected localities of the Nitra river basin, we observed the occurrence of meteorological drought not only in the summer months, but also in spring and autumn. However, this drought is interrupted by precipitation and does not fully correspond to the agricultural (soil) drought, which lasts for a longer period. It is therefore necessary to focus research on the impact of these two droughts, but also on the soil characteristics in specific localities.

\section{Acknowledgments}

This publication was supported by the Operational Programme Integrated Infrastructure within the project: Sustainable smart farming systems taking into account the future challenges $313011 \mathrm{~W} 112$, co-financed by the European Regional Development Fund; by Grant Agency of SUA in Nitra under the contract No. GA SPU 03-GASPU2018; by This work was supported by the Cultural and Educational Grant Agency KEGA 026SPU-4/2020 and by the Operational Program Integrated Infrastructure within the project: Demand-driven research for the sustainable and innovative food, Drive4SIFood 313011V336, co-financed by the European Regional Development Fund.

\section{References}

Antal, J., Bárek, V., Čimo, J., Halaj, P., Halászová, K., Horák, J. et al. (2014). Hydrology of agricultural land. Nitra: SPU (in Slovak).

Báreková, A., Bárek, V., Kováčová, M., Novotná, B., Kišš, V. (2020). Climate conditions impact on the sap flow into plants and their dendrometric changes, Journal of Ecological Engineering, 21(6), 224-228. DOI 10.12911/22998993/124077

Bhuiyan, Ch. (2017). Drought Vulnerability. In Eslamian, S., \& Eslamian, F. A. (Ed.). Handbook of Drought and Water Scarcity: Environmental Impacts and Analysis of Drought and Water Scarcity Florida: CRC Press (689 p).

Borgula, A. (26.11.2020). Nitra river around city Nitra. http://riekanitra.szm.com (in Slovak).

Brezianská, K., Vitková, J. (2015). Analyse of periods without precipitation and their influence on soil water storage at Záhorská Lowland. Acta Hydrologica Slovaca, 16(TC1), 260-266 (in Slovak).

Chen, Ch. (2018). Identifying Critical Climate Periods for Vegetation Growth in the Northern Hemisphere. JGR Biogeosciences, 123(8), 2541-2552. https://doi.org/10.1029/2018JG004443

Čimo, J., Aydin, E., Šinka, K., Tárník, A., Kišš, V., Halaj, P., Toková, L., Kotuš, T. (2020). Change in the Length of the Vegetation Period of Tomato (Solanum lycopersicum L.), White Cabbage (Brassica oleracea L. var. capitata) and Carrot (Daucus carota L.) Due to Climate Change in Slovakia. Agronomy, 10(8), 1110. https://doi. org/10.3390/agronomy 10081110

Coles, N. A., Eslamian, S. (2018). Definition of Drought. In: Eslamian, S., and Eslamian, F. A. (Ed.), Handbook of Drought and Water Scarcity: Principles of Drought and Water Scarcity Florida: CRC Press (690 p.).

De Luis, M., Gonzalez-Hidalgo, J. C., Longares, L. A., Stepanek, P. (2008). Seasonal precipitation trends in the Mediterranean Iberian 
Peninsula in second half of $20^{\text {th }}$ century. International Journal of Climatology, 29(9), 1312-1323. https://doi.org/10.1002/joc.1778

De Luis, M., Cufar, K., Saz, M. A., Longares, L. A., Ceglar, A., Bogataj, L. K. (2014). Trends in seasonal precipitation and temperature in Slovenia during 1951-2007. Regional Environmental Change, 14, 1801-1810. https://doi.org/10.1007/s10113-012-0365-7

Dracup, J. A., Lee, K. S., Paulson Jr., E. G. (1980). On the definition of droughts. Water Resource Research, 16(2), 297-302. https://doi.org/10.1029/WR016i002p00297

Eklund, L., Seaquist, J. (2015). Meteorological, agricultural and socioeconomic drought in the Duhok Governorate, Iraqi Kurdistan. Natural Hazards, 76, 421-441. DOI 10.1007/s11069-014-1504-x

Engstrőm, J., Jafarzadegan, K., Moradkhani, H. (2020). Drought Vulnerability in the United States: An Integrated Assessment. Water, 12(7), 2033. https://doi.org/10.3390/w12072033

Guo, Y., Huang, S., Huang, Q., Wang, H., Fang, W., Yang, Y., Wang, L. (2019). Assessing socioeconomic drought based on an improved Multivariate Standardized Reliability and Resilience Index. Journal of Hydrology, 568, 904-918. https://doi.org/10.1016/j. jhydrol.2018.11.055

Igaz, D., Štekauerová, V., Horák, J., Kalúz, K., Čimo, J. (2011). The Analysis of Soils Hydrophysical Characteristics in the Nitra River Basin. Influence of Anthropogenic Activities on Water Regime of Lowland Territory Physics of Soil Water (pp. 17-19) (in Slovak).

Kutílek, M., Nielsen D. R. (1994). How Water Flows in Soil. Soil. Dordrecht: Springer. https://doi.org/10.1007/978-94-017-9789-4_9 Łabędzki, L., Bąk, B. (2014). Meteorological and agricultural drought indices used in drought monitoring in Poland: a review. Meteorology, Hydrology and Water Management, 2(2), 12.

Lecina-Diaz, J., Martínez-Vilalta, J., Alvarez, A., Banqué, M., Birkmann, J., Feldmeyer, D., Vayreda, J., Retana, J. (2020). Characterizing forest vulnerability and risk to climate-change hazards. Frontiers in Ecology and the Environment, 19(2), 126-133. https://doi.org/10.1002/ fee. 2278

Lloyd-Hughes, B. (2013). The impracticality of a universal drought definition, Theoretical and Applied Climatology, 117(3-4), 607-611. https://doi.org/10.1007/s00704-013-1025-7

Mannocchi, F., Todisco, F., Vergni, L. (2004). Agricultural drought: indices, definition and analysis. Proceedings of the UNESCO/IAHS/ IWIIA symposium (pp. 246-254).

Mazúr, E., Lukniš, M. (1980). Geomorphological division. Atlas SSR. Bratislava: Slovenská akadémia vied, SÚGK (in Slovak).

Mehran, A., Mazdiyasni, O., AghaKouchak, A. (2015). A hybrid framework for assessing socioeconomic drought: Linking climate variability, local resilience, and demand. Journal of Geophysical Research, 120(15), 7520-7533. DOI: 10.1002/2015JD023147

Pal, I., Al-Tabbaa, A. (2009). Trends in seasonal precipitation extremes - An indicator of 'climate change' in Kerala, India. Journal of Hydrology, 367(1-2), 62-69. https://doi.org/10.1016/j. jhydrol.2008.12.025

Palmer, W. C. (1965). Meteorological Drought. Washington, D.C.: U.S. Weather Bureau.

Petrovič, Š. (1960). Climatic Conditions of Hurbanovo. Praha: HMÚ (pp. 138-161) (in Slovak).

Plich, J. (2017). Evaluation of the Length of the Vegetation Period of the Potato. Plant Breeding and Seed Science, 76, 65-67. DOI: 10.1515/ plass-2017-0023

Quiring, S. M. (2009). Monitoring Drought: An Evaluation of Meteorological Drought Indices. Geography Compass, 3(1), 64-88. https://doi.org/10.1111/j.1749-8198.2008.00207.x

Salman, S. A., Shahid, S., Ismail, T., Ahmed, K., Chung, E. S., Wang, X. J. (2019). Characteristics of Annual and Seasonal Trends of Rainfall and Temperature in Iraq. Asia-Pacific Journal of Atmospheric Sciences, 55, 429-438. https://doi.org/10.1007/s13143-018-0073-4
Sar, T., Avci, S., Avci, M. (2019). Evaluation of the Vegetation Period According to Climate Change Scenarios: A Case Study in the Inner West Anatolia Subregion of Turkey. Journal of Geography, 39, 29-39. https://doi.org/10.26650/JGEOG2019-0018

Seshasai, M. V. R., Murhy, C. S., Chandrasekar, K., Mohammed, A. J., Prabir, K. D. (2016). Agricultural drought: Assessment \& monitoring. Mausam, 67(1), 131-142.

Stahl, K., Vidal, J. P., Hannaford, J., Tijdeman, E., Laaha, G., Gauster, T., Tallaksen, L. M. (2020). The challenges of hydrological drought definition, quantification and communication: an interdisciplinary perspective. Proceedings of the International Association of Hydrological Sciences, 383, 291-295. https://doi.org/10.5194/ piahs-383-291-2020

Šútor, J., Gomboš, M., Mati, R. (2005). The Quantification of Soil Drought and Its Performance. Acta Hydrologica Slovaca, 6(2), 299306 (in Slovak).

Šútor, J., Šurda, P., Štekauerová, V. (2011). Effect of the time periods without precipitation on water storage dynamics in the aeration zone of the soil. Acta Hydrologica Slovaca, 12(1), 22-28 (in Slovak).

Toková, L. (2019). Using Gravimetric Method for Soil Moisture Determination. Veda Mladých 2019 - Science of Youth 2019 (pp. 122-130).

Tu, X., Wu, H., Singh, V. P., Chen, X., Lin, K., Xie, Y. (2018). Multivariate design of socioeconomic drought and impact of water reservoirs. Journal of Hydrology, 566, 192-204. https://doi.org/10.1016/j. jhydrol.2018.09.012

Van Loon, A. F. (2015). Hydrological drought explained. Wires Water, 2(4), 359-392. https://doi.org/10.1002/wat2.1085

Vitková, J., Šútur, J., Šurda, P., Stradiot, P. (2015). Possibilities of interpretation of monitored values of water supplies in soil. Acta Hydrologica Slovaca, 16(1), 3-12.

Wandel, J., Diaz, H., Warren, J., Hadarits, M., Hurlbert, M., Pittman, J. (2016). Drought and Vulnerability: A Conceptual Approach. In Diaz, H., Hurlbert, M., Warren, J. (Ed.). Vulnerability and Adaptation to Drought on the Canadian Prairies. Calgary: Univesity of Calgary Press (pp. 15-38). https://doi.org/10.2307/j.ctv6gawv1.4

Wang, W., Ertsen, M. W., Svoboda, M. D., Hafeez, M. (2016). Propagation of Drought: From Meteorological Drought to Agricultural and Hydrological Drought. Advances in Meteorology, 2016, 5. https://doi.org/10.1155/2016/6547209

Wilhite, D. A., Glantz, M.H. (1985). Understanding the Drought Phenomenon: The Role of Definitions. Water International, 10(3), 111-120.

World Meteorological Organization (WMO), Global Water Partnership (GWP). (2016). Handbook of Drought Indicators and Indices. In:Svoboda, M., Fuchs, B. A. Integrated Drought Management Programme (IDMP). Integrated Drought Management Tools and Guidelines Series 2. Geneva.

Zhai, P., Zhang, X., Wan, H., Pan, X. (2005). Trends in Total Precipitation and Frequency of Daily Precipitation Extremes over China. Journal of Climate, 18(7), 1096-1108. https://doi.org/10.1175/JCLI-3318.1

Zhong, F., Cheng, Q., Wang, P. (2020). Meteorological Drought, Hydrological Drought, and NDVI in the Heihe River Basin, Northwest China: Evolution and Propagation. Advances in Meteorology, 2020, 26. https://doi.org/10.1155/2020/2409068 